\title{
Sinaloa Tomato Leaf Curl Geminivirus: Biological and Molecular Evidence for a New Subgroup III Virus
}

\author{
A. M. Idris and J. K. Brown
}

Department of Plant Sciences, University of Arizona, Tucson 85721.

Accepted for publication 1 April 1998.

\begin{abstract}
Idris, A. M., and Brown, J. K. 1998. Sinaloa tomato leaf curl geminivirus: Biological and molecular evidence for a new subgroup III virus. Phytopathology 88:648-657.

The biological and molecular properties of Sinaloa tomato leaf curl virus (STLCV) were investigated in line with the hypothesis that STLCV is a previously uncharacterized, whitefly-transmitted geminivirus from North America. STLCV causes yellow leaf curl symptoms in tomato and yellow-green foliar mottle in pepper. Five species belonging to two plant families were STLCV experimental hosts. STLCV had a persistent relationship with its whitefly vector, Bemisia tabaci. Polymerase chain reaction fragments of STLCV common region (CR) sequences of the A or $\mathrm{B}$ genomic components and the viral coat protein gene $(A V I)$ were molecularly cloned and sequenced. The STLCV A- and B-component CR sequences (174 nucleotides each) shared $97.9 \%$ identity and contained
\end{abstract}

ABSTRACT

identical cis elements putatively involved in transcriptional regulation and an origin of replication (the AC cleavage site within the loop of the hairpin structure and two direct repeat sequences thought to constitute the Rep binding motif), which collectively are diagnostic for subgroup III geminiviruses. The STLCV CR sequence shared 23.1 to $77.6 \%$ identity with CR sequences of representative geminiviridae, indicating the STLCV $\mathrm{CR}$ sequence is unique. Molecular phylogenetic analysis of $\mathrm{CR}$ or AV1 sequences of STLCV and the respective sequences of 31 familial members supported the placement of STLCV as a unique bipartite, subgroup III virus most closely related to other viruses from the Western Hemisphere. STLCV is provisionally described as a new species within the genus Begomovirus, family Geminiviridae.

Additional keywords: pepper virus, solanaceous virus, whitefly-transmitted virus.

Whitefly-transmitted (WFT) geminiviruses have long been recognized as serious pathogens of crop plants in the subtropical Americas $(22,52)$. With the upsurge of whitefly vector populations throughout the Americas during the 1970s and 1980s $(9,10,12)$ and the introduction of an exotic whitefly vector circa 1986 (24), WFT geminiviruses have become increasingly problematic pathogens in vegetable-cotton production agroecosystems $(9,10,80)$.

WFT geminiviruses are placed in the genus Begomovirus (subgroup III), family Geminiviridae. They infect dicotyledonous plants (59) and have circular, single-stranded DNA genomes of 2.8 to $5.2 \mathrm{~kb}$, with a monopartite or bipartite arrangement, respectively $(6,55)$. Bipartite geminivirus genomes have a large noncoding region, $\approx 200$ nucleotides (nt) long, termed the common region (CR). The $\mathrm{CR}$ contains modular $c i s$-acting sequences involved in transcriptional regulation of certain viral genes and the sequence elements essential for virus replication, which are collectively identical features of cognate A and B components of a given virus $(11,55,62)$.

The A component of bipartite geminiviruses contains five open reading frames (ORFs) capable of encoding proteins larger than $10 \mathrm{kDa}$. The viral capsid protein is encoded by the AV1 ORF and is the most highly conserved gene within the family Geminiviridae (40). The AC1 ORF encodes a polypeptide involved in replication (41), the AC2 ORF encodes a transcriptional activator (TrAP), the AC3 ORF encodes a replication enhancer (REn), and the AC4 ORF encodes a polypeptide involved in transcriptional regulation $(6,31,55,69,77,78)$. The B component encodes two polypeptides, each required for aspects of systemic infection (55). ORFs primarily analogous to those of the A component of bipartite viruses also are found in the monopartite genomes of WFT geminiviruses.

Corresponding author: J. K. Brown; E-mail address: jbown@ag.arizona.edu

Publication no. P-1998-0515-01R

(C) 1998 The American Phytopathological Society
In addition, an AV2 has been discovered that encodes a viral movement function for a monopartite geminivirus (63).

Demonstration of infectivity and development of systemic symptoms in planta after inoculation of cognate cloned bipartite geminivirus genomes provide proof of effective trans-activation or complementation of replication functions, as well as demonstrating competence of systemic movement and, thereby, definitively proving Koch's postulates of pathogenicity. Consequently, it is possible to hypothesize that $\mathrm{A}$ and $\mathrm{B}$ genomic components sharing identical sequences and context within the CR sequence elements are capable of establishing a viable systemic infection, providing direct proof of the cognate nature of their bipartite genomic components. Further, it has been proposed that the ability of viral component(s) to complement through reciprocal exchange with an already described virus provides a basis for the tentative taxonomic classification of the isolate in question as a strain of the existing viral species. In contrast, CR sequence incongruence between genomic components and, consequently, their inability to trans complement replication and establish a viable infection are grounds for hypothesizing a distinct or new viral species. In all cases, proof of infectivity and systemic infection must ultimately be provided.

The use of the viral $A V I$ sequence to achieve tentative taxonomic placement of a virus within the family Geminiviridae also is generally accepted. Trees reconstructed from $A V 1$ sequences are indistinguishable from those predicted by the A-component sequences of bipartite viruses and the sequences of monopartite virus genomes $(62,71,83)$. Further, an arbitrary guideline has been suggested by which to estimate taxonomic relatedness based on the $A V 1$ sequence. Using this approach, a coat protein (CP) gene sequence sharing $>90 \%$ identity with another would constitute a strain of an existing virus, whereas $<90 \%$ shared identity would suggest a separate species.

The establishment of the exotic B biotype whitefly vector, whose origin is thought to be in the Eastern Hemisphere $(15,35)$, has 
been implicated as an important factor in the recent (post-1986) emergence of geminiviruses in solanaceous crops in the subtropical Americas (15). In comparison to the indigenous A-like Bemisia tabaci (Genn.), the host range of the B biotype is quite extensive (15), and the B biotype has a great propensity for species of the Solanaceae and Malvaceae, species which are suspected sources of emerging geminiviruses. Although the A biotype of $B$. tabaci is indigenous (or recently so) to the New World (14), pre1986 , local populations were known to colonize solanaceous (4) or euphorbiaceous $(5,23)$ species in a transient manner, a phenomenon associated with their dispersal from other crop species at the culmination of the cropping season. For these reasons, pepperand tomato-infecting geminiviruses were poorly described in the Americas prior to 1986 .

The chronological history of WFT geminivirus diseases of tomato and pepper from Mexico and the Southwestern United States confirms the predominantly recent emergence of these viral pathogens in solanaceous crops. The most well-studied geminiviruses include chino del tomato (CdTV) $(18,36)$; pepper mild tigre (PMTV) (13); serrano golden (SGMV); Texas pepper virus (TPV-Tamaulipas strain), formerly pepper jalapeño virus (76); pepper hausteco virus (PHV) (37); tomato mottle virus (ToMoV) (2); and tomato leaf crumple virus (TLCrV) (64). A comprehensive list of tomatoinfecting geminiviruses found in the Americas, including isolates for which there is insufficient information to permit naming or accurate taxonomic placement, is available (65).

Here, we report the biotic and partial molecular characterization of a new geminivirus, the causal agent of a debilitating and widespread disease in tomato and pepper first observed in Sinaloa, Mexico, in 1989. Infected tomato plants exhibit foliar curling and chlorosis, unique purpling on the abaxial side of leaves, and shortened internodes. Infected pepper plants exhibit a green-yellow foliar mosaic, shortened internodes, and stunting (16). The causal agent was tentatively described as a WFT geminivirus, based on positive whitefly transmissibility and DNA-DNA hybridization experiments, and was designated Sinaloa tomato leaf curl virus (STLCV) $(16,49)$. Here, we provide definitive evidence based on biological and molecular sequence data that STLCV is a new, bipartite subgroup III geminivirus from the Western Hemisphere that is unique from all other solanaceous crop-infecting geminiviruses described to date.

\section{MATERIALS AND METHODS}

Host range. Plants used in the host range study were representative, cultivated crop or weed species common to Sonoran Desert agroecosystems (Table 1). Three seeds were sown per $8-\mathrm{cm}$-diameter plastic pot and later thinned to one seedling per pot. At least four seedlings of each test species were inoculated with STLCV, using 15 to 20 viruliferous adult whiteflies per transmission experiment, except for eggplant, which was biolistically inoculated with $10 \mu \mathrm{l}$ of total DNA extract from a STLCV-infected tomato plant (19). Whitefly transmission parameters were a 24-h acquisition access period (AAP) and a 48-h inoculation access period (IAP), unless otherwise stated. All transmission experiments were conducted in an environmentally controlled growth chamber $\left(27^{\circ} \mathrm{C}\right.$, $12 \mathrm{~h}$ day/night cycle). Experimental controls consisted of plants exposed to whiteflies from a virus-free colony and plants that were maintained whitefly-free. Transmission experiments were terminated by fumigation with nicotine sulfate to kill the whiteflies. Inoculated plants were maintained in an insect-free greenhouse or growth chamber while under observation for development of symptoms. Each experiment was replicated three times.

Plants were bioassayed for STLCV infection 3 to 4 weeks postinoculation by whitefly transmission to tomato cv. Pole Boy seedlings (3- to 4-leaf stage). Back-inoculations were carried out with 15 to 20 nonviruliferous whiteflies per plant, a 24-h AAP on source plants and 48-h IAP on indicator plants. Tomato indicator plants were fumigated as described, and plants were maintained in a whitefly-free growth chamber or greenhouse and monitored for symptom development. The appearance of characteristic STLCV symptoms in cv. Pole Boy tomato within 8 to 12 days postinoculation (DPI) was considered indicative of positive STLCV infection.

Virus-vector relationships. Tomato cv. Pole Boy was used as the virus source and diagnostic indicator species. Minimum and maximum acquisition-access transmission parameters were determined for STLCV with the A biotype whitefly. The experiment was replicated, six plants per replication. In these experiments, 15 virus-free whiteflies were given an AAP of either 0.5, 1, 2, 4, 10, 12 , or $18 \mathrm{~h}$ on a STLCV-infected tomato plant, followed by a 24-h IAP on a healthy tomato seedling. Optimum IAPs were determined by allowing 15 virus-free A biotype whiteflies a 24-h AAP on the virus source plant, followed by IAPs of $0.5,1,2,4,10,12$, or $18 \mathrm{~h}$, on tomato seedlings. The latent period of STLCV in the whitefly vector was estimated based on experimentally determined minimum and maximum AAPs and IAPs for which positive transmission could be shown. The length of time STLCV persisted in adult whiteflies was determined with whiteflies given a 48-h AAP on virus source plants, followed by serial transfer of single whiteflies to virus-free tomato seedlings at 24-h intervals for 14 consecutive days or until whiteflies were not found alive.

Transovarial passage. The potential for transovarial passage of STLCV to whitefly progeny was evaluated by caging 10 pairs of viruliferous A type whiteflies on cv. Delta Pine 70 cotton, a species immune to STLCV, for 1 week to oviposit. After fumigation, cotton plants were placed in nylon mesh cages. Eggs were permitted to hatch and progeny to develop to maturity. Adults that

TABLE 1. Host range study of Sinaloa tomato leaf curl virus, as determined by whitefly-mediated transmission ${ }^{\mathrm{a}}$

\begin{tabular}{|c|c|c|}
\hline Test plant & $\begin{array}{l}\text { Symptomatic plants/ } \\
\text { inoculated plants }{ }^{\mathrm{b}}\end{array}$ & $\begin{array}{l}\text { Back-inoculation } \\
\text { results }^{c}\end{array}$ \\
\hline \multicolumn{3}{|l|}{ Compositeae } \\
\hline \multicolumn{3}{|l|}{ Ambrosia deltoidea (Torr.) } \\
\hline Payne & $0 / 12$ & - \\
\hline \multicolumn{3}{|l|}{ Cucurbitaceae } \\
\hline Citrullus vulgaris Schrad & $0 / 12$ & - \\
\hline Cucumis melo $\mathrm{L}$. & $0 / 13$ & - \\
\hline Cucumis sativus $\mathrm{L}$. & $0 / 12$ & - \\
\hline Cucurbita maxima Duchnes. & $0 / 13$ & - \\
\hline Cucurbita pepo L. & $0 / 12$ & - \\
\hline \multicolumn{3}{|l|}{ Leguminosae } \\
\hline Cajanus cajan (L.) Huth & $0 / 12$ & - \\
\hline Glycine $\max (\mathrm{L}$.$) Merr.$ & $0 / 12$ & - \\
\hline Phaseolus vulgaris L. & $0 / 14$ & - \\
\hline $\begin{array}{l}\text { Vigna unguiculata subsp. } \\
\text { unguiculata L. Walp. }\end{array}$ & $0 / 12$ & - \\
\hline \multicolumn{3}{|l|}{ Malvaceae } \\
\hline Abutilon theophrasti Medik. & $0 / 12$ & - \\
\hline Gossypium hirsutum L. & $0 / 13$ & - \\
\hline Malva parviflora $\mathrm{L}$. & $11 / 15$ & + \\
\hline Sida alba $\mathrm{L}$. & $0 / 13$ & - \\
\hline \multicolumn{3}{|l|}{ Solanaceae } \\
\hline Capsicum аппиит L. & $9 / 15$ & + \\
\hline Datura metel L. & $9 / 14$ & + \\
\hline D. stramonium L. & $7 / 12$ & + \\
\hline Nicotiana glutinosa $\mathrm{L}$. & $0 / 12$ & - \\
\hline N. tobacum L. & $0 / 13$ & - \\
\hline & $0 / 12$ & - \\
\hline \multicolumn{3}{|l|}{ Solanum lycoperiscon } \\
\hline L. (Karsten) & $15 / 15$ & + \\
\hline
\end{tabular}

${ }^{a}$ A 24-h acquisition access period on virus source plants and 48-h inoculation access period on test plants were used.

${ }^{b}$ Number of plants with symptoms/total number of inoculated plants.

c Virus infection was confirmed by back-inoculation to cv. Pole Boy tomato plants. $+=$ susceptible $;-=$ immune. 
eclosed $\approx 21$ to 30 days later were collected at the end of the teneral period and transferred to tomato seedlings (15 to 20 per plant) for a 3-day IAP. Whiteflies were fumigated, and tomato plants were observed for development of characteristic STLCV symptoms. Nine seedlings were exposed to the progeny of viruliferous females in each of three experiments.

Mechanical transmission. Inoculum was prepared by grinding STLCV-infected, symptomatic tomato leaves in a mortar and pestle with 1:4 (wt/vol) $0.2 \mathrm{M}$ potassium phosphate buffer ( $\mathrm{pH}$ 7.6) containing diatomaceous earth. Twelve tomato, pepper, or Datura stramonium plants and six Nicotiana tabacum cv. Samsun or $N$. benthamiana plants were inoculated in each of three experiments. Plants were maintained in an insect-free greenhouse and observed periodically for characteristic symptom development for 3 weeks.

Total nucleic acid extraction. Nucleic acids were extracted from symptomatic tomato leaves (12 DPI), following the method
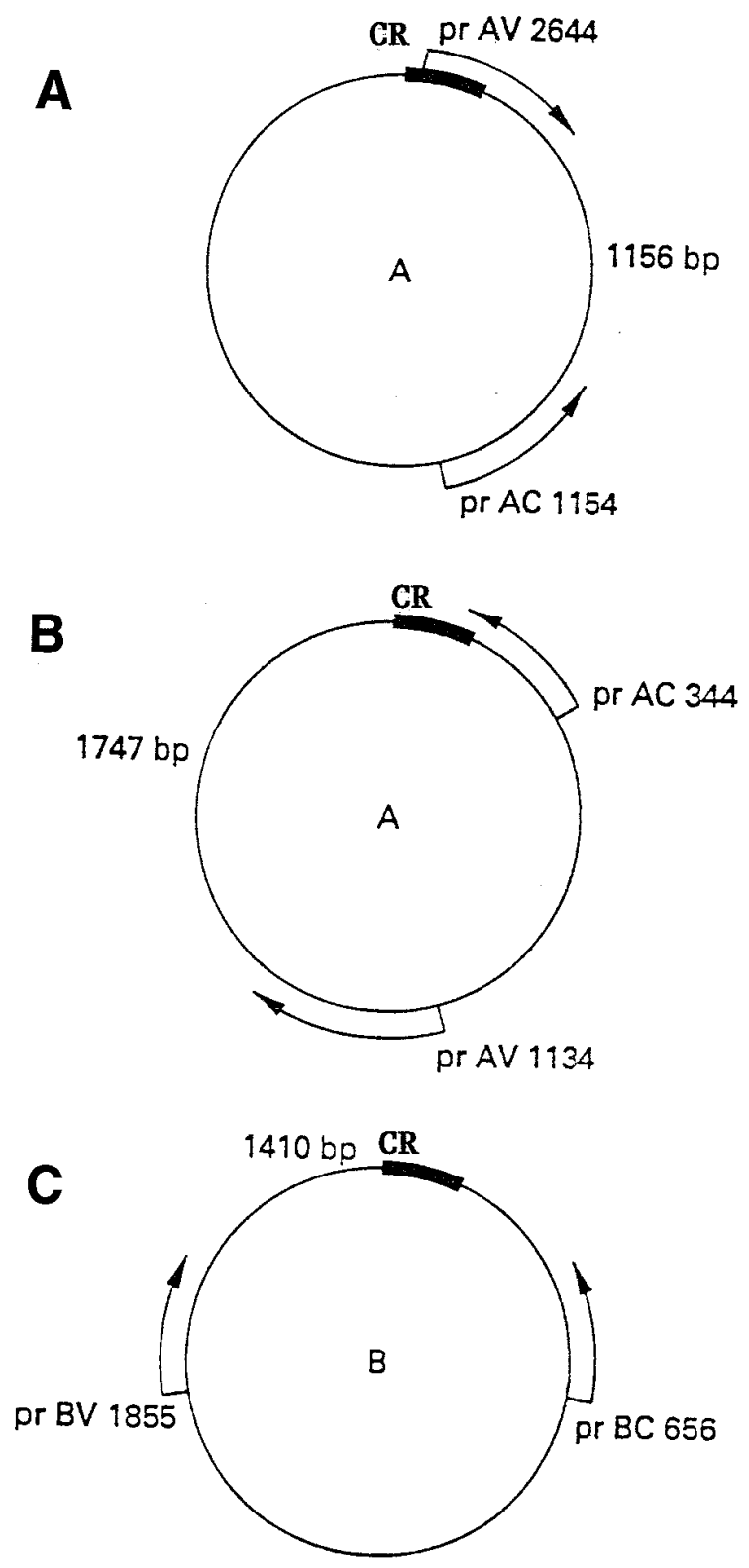

Fig. 1. Locations of polymerase chain reaction (PCR) primer annealing sites on A and B components of bipartite subgroup III geminiviruses and the expected sizes of PCR products. A, prAV 2644/prAC 1154 to direct the amplification of a 1,156-bp fragment containing AV1; B, prAV 1134/prAC 344 to direct the amplification of a 1,747-bp fragment containing the common region (CR)-A sequence; and C, prBV 1855/prBC 656 to direct the amplification of a 1,410-bp fragment containing the CR-B sequence. of Doyle and Doyle (29) with minor modifications. Leaves were ground to powder while frozen in liquid nitrogen and immediately suspended in warm $\left(60^{\circ} \mathrm{C}\right)$ cetyltrimethylammonium bromide buffer. Homogenates were extracted with an equal amount of chloroform/isoamyl alcohol (24:1, vol/vol), phases were separated by centrifugation at $9,000 \times g$ for $10 \mathrm{~min}$ at $4^{\circ} \mathrm{C}$, and supernatants were precipitated overnight with two-thirds volume of isopropyl alcohol. Nucleic acids were collected by centrifugation at 9,000 $\times g$ for $10 \mathrm{~min}$ at $4{ }^{\circ} \mathrm{C}$, washed with one volume of wash buffer containing $76 \%$ ethanol and $0.2 \mathrm{M}$ sodium acetate, and collected by microcentrifugation at $4^{\circ} \mathrm{C}$. Pellets were air- or vacuum-dried and resuspended (1:1, wt/vol) in Tris-EDTA buffer, $\mathrm{pH} 8.0$, containing $1 \mathrm{M}$ Tris and $1 \mathrm{mM}$ EDTA.

Polymerase chain reaction (PCR), cloning, and DNA sequencing. The $\mathrm{CR}$ of the DNA A and B genomic components and the CP gene $(A V l)$ of STLCV were amplified by PCR (72) and one of three pairs of degenerate primers, respectively (Fig. 1) (S. D. Wyatt and J. K. Brown, unpublished data). The design of PCR primers was based on highly conserved regions of the genome identified by alignment of sequences of representative subgroup III geminiviruses. PCR primers used to amplify the CR and its flanking sequences of STLCV component A were prAV1134 (5' CGTCCA(A/G)ACTT(G/T) GAA(A/G)TT(G/C)AG 3') and prAC344(5' CT(G/T)GGCTT(C/T)CT(A/G) TACAT(AG)GGC 3'). Primers prBV1855(5' AC(AG)CAA A/G)TG(G/A)TC(T/G)AT(C/T) TTCAT $\left.3^{\prime}\right)$ and prBC656(5' TT(A/C/G)AC(A/C)GTCCCTTTGAAACG $\left.3^{\prime}\right)$ were used to amplify the $\mathrm{CR}$ and flanking sequences of the viral B component. The AV1 ORF and flanking sequences were amplified with prAC1154(5' CT(G/C)AA(C/T)TTC (A/C)AAGT(C/T)TGGACG 3') and prAV2644(5' ATTACCGGATGGCCGC $3^{\prime}$ ). Primers were synthesized at the Biotechnology Facility, University of Arizona, Tucson.

PCR reactions were conducted with a Perkin-Elmer (Norwalk, CT) DNA thermal cycler. Reaction mixtures $(25 \mu \mathrm{l})$ contained $0.5 \mu$ of DNA extract $(\approx 1 \mu \mathrm{g}$ of DNA) of STLCV-infected tomato plants, 2.5 or $3.0 \mathrm{mM} \mathrm{MgCl}{ }_{2}, 1 \times$ reaction buffer $(10 \mathrm{mM}$ Tris$\mathrm{HCl}, 50 \mathrm{mM} \mathrm{KCl}, \mathrm{pH} 8.0), 150 \mu \mathrm{M}$ dNTPs, and $20 \mathrm{pmol}$ of each primer. Taq DNA polymerase was used according to the manufacturer's specifications (Perkin-Elmer). DNA amplification parameters were 30 cycles of denaturation at $95^{\circ} \mathrm{C}$ for $1 \mathrm{~min}$, primer annealing at $60^{\circ} \mathrm{C}$ for $1 \mathrm{~min}$ (except for CR-A primers, which was $63^{\circ} \mathrm{C}$ for $1 \mathrm{~min}$ ), and primer extension at $72^{\circ} \mathrm{C}$ for $1 \mathrm{~min}$, with a

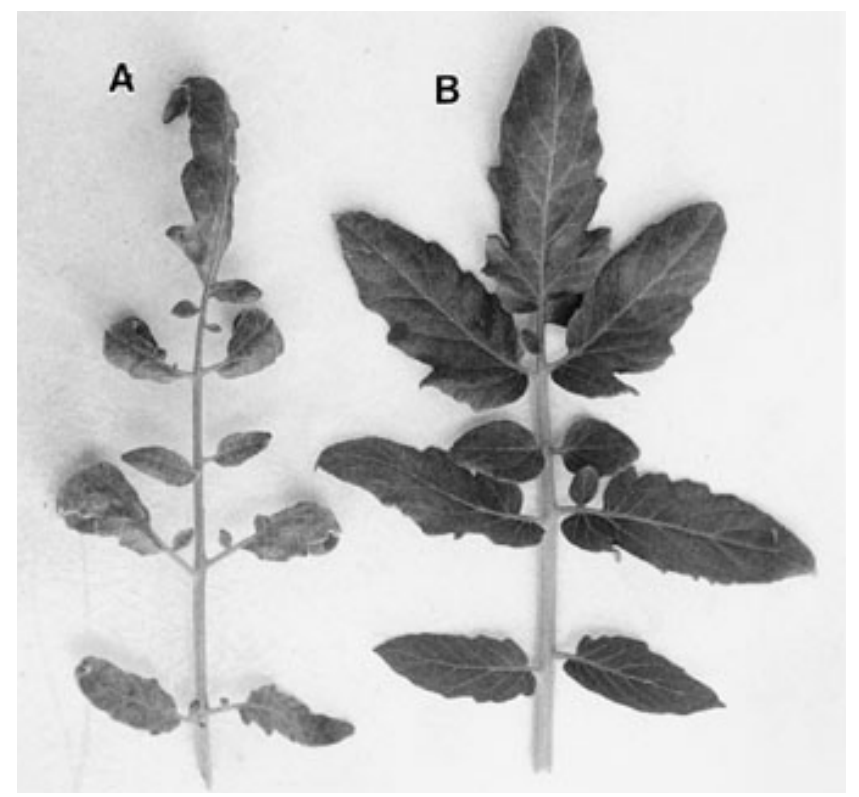

Fig. 2. A, Disease symptoms in a tomato leaf infected with Sinaloa tomato leaf curl geminivirus 2 to 3 weeks postinoculation; B, healthy tomato leaf. 
final cycle of $5 \mathrm{~min}$ at $72^{\circ} \mathrm{C}$. The temperature was reduced to $4{ }^{\circ} \mathrm{C}$ until samples were removed. PCR products were electrophoresed in $1 \%$ agarose gels in Tris-acetate-EDTA buffer, $\mathrm{pH}$ 8.0. Gels were stained with ethidium bromide and viewed by UV transillumination.

Cloning and sequencing of PCR products. PCR products of the expected sizes were cloned into a plasmid vector (pCR 2.1) with a TA cloning kit (Invitrogen, San Diego, CA), following the manufacturer's instructions. Fragments containing putative DNA $\mathrm{A}$ and $\mathrm{B}$ CR sequences were identified by size approximation in miniprep screening, and clones were confirmed as positive for viral inserts based on the respective PCR primers used for amplification. Sequences were obtained in both directions for a minimum of two clones by automated sequencing with an Applied Biosystems (Foster City, CA) 373A sequencer at the Molecular Genetics Facility, University of Georgia, Athens.

Computer analysis of geminivirus sequences. Virus sequences were assembled in forward and reverse directions by SeqEdit and Align programs (DNASTAR Inc., Madison, WI). The amino acid sequence of STLCV AV1 was deduced from its nucleotide sequence by SeqEdit. The CR and $A V I$ sequences of representative geminiviruses were compiled by truncating full-length sequences from GenBank. CR sequences and their deduced amino acid sequences were compared with Align, which utilizes the WilburLipman algorithm (DNASTAR).

$A V 1$ sequences were aligned by Clustal, the alignment algorithm used in the MegAlign program (DNASTAR). This software aligns sequences by a distance method with progressive, stepwise sequence comparisons and generates an arithmetic mean for all subsequent pairwise comparisons. This approach makes no a priori assumptions about evolutionary histories. The percent similarity between sequences is calculated by $100 \times$ sum of matching residues/[(length - gap residues (sequence 1) - gap residues (sequence 2)]. The $A V 1$ tree reconstructed by Clustal was examined further by maximum parsimony (MP) analysis with phylogenetic analysis using parsimony (PAUP), version 3.1.1 (79). A most parsimonious tree was predicted by a heuristic search method with stepwise addition, tree bisection-reconnection, and random branchswapping options (79). The parsimony reconstruction was generated after 100 iterations of bootstrap sampling, 10 replicates each. Bootstrap values (50\% majority rule) were placed on nodes of the most parsimonious tree.

Geminiviruses used in sequence comparisons are as follows (abbreviations and GenBank accession numbers are shown parenthetically): Abutilon mosaic virus (AbMV, X15983) (34); African cassava mosaic virus-Kenya (ACMV-Ke, J02057) (74); ACMVNigeria (ACMV-Ni, X17095) (57); Ageratum yellow vein virus (82); bean dwarf mosaic virus (BDMV, M88179) (42); bean golden mosaic virus-Brazil (BGMV-BR, M88686) (38); BGMV-Dominican Republic (BGMV-DR, L01635) (32); BGMV-Jamaica (BGMVJam); BGMV-Guatemala (BGMV-Ga, M91604) (32); BGMV-Puerto Rico (BGMV-PR, M10070) (47); beet curly top virus (BCTV, M24597) (75); cabbage leaf curl virus (U65529) (1); Digitaria streak virus (M23022) (28); Indian cassava mosaic virus (Z24758) (46); maize streak virus-Kenya (MSV-Ke, X01089) (48); mung bean yellow mosaic virus (D14703) (56); PHV (X70418) (81); TPVTamaulipas (U57457) (80); potato yellow mosaic virus (D00940) (26); Sida golden mosaic virus (X99550) (43); squash leaf curl virus-E (SqLCV-E, M38182) (54); SqLCV-China (SqLCV-Ch, S77090) (44); Taino tomato mottle virus (TTMoV, AF012300) (67); tomato golden mosaic virus (TGMV, K02029) (39); TLCrV (L34747) (64); tomato leaf curl virus-Australia (ToLCV-AU, S53251) (30); ToLCV-New Delhi (ToLCV-ND, U15015) (61); Indian tomato leaf curl virus (IToLCV, Z48182) (45); IToLCV-Bangalore II (IToLCVBanII, U38239) (20); ToLCV-Taiwan (ToLCV-TW, U88692); ToMoV (L14460) (2); tomato pseudo-curly top virus (X84735) (8); tomato yellow leaf curl virus-Israel (TYLCV-Is, X15656) (60); TYLCVSardinia (TYLCV-Sar, X61153) (51); TYLCV-Thailand (TYLCVTH, M59838) (70); and tobacco yellow dwarf virus (M81103) (58).

\section{RESULTS}

Host range and symptom phenotypes. Among the 21 species in 5 plant families inoculated with STLCV, a species was identified as a virus host based on development of characteristic STLCV symptoms in tomato seedlings after back-inoculation by the whitefly vector. Among those examined, only five species, either within the Malvaceae or Solanaceae, were susceptible to STLCV infection (Table 1). Experimental hosts identified in this study were $D$. metel, D. stramonium, cheeseweed (Malva parviflora), pepper (Capsicum annuum), and tomato (Solanum lycopersicon). No species within the Cucurbitaceae or Leguminosae that are widely grown in the Sonoran Desert were identified as hosts of STLCV.

Symptoms of STLCV infection on developing leaves of infected tomato seedlings included severe downward curling, yellowing, distortion, veinal chlorosis, and moderate stunting (Fig. 2). Older leaves developed mild mottling symptoms with leaf curling, and the underside of leaves exhibited reddening or purpling, similar to that associated with anthocyanin accumulation due to phosphorous deficiency. Affected pepper leaves exhibited a splotchy green-yellow mottle that persisted on both older and newly developing leaves (Fig. 3). D. metel plants developed mild foliar distortion, whereas $D$. stramonium exhibited leaf mottling and distortion. STLCV symptoms in M. parviflora included severe leaf mottling and distortion and stunting. Disease symptoms developed in all symptomatic hosts within 10 to 14 DPI. Geminivirus infections in species scored as hosts based on symptom development were confirmed by PCR with degenerate primers that yield an $\approx 550$-bp fragment of the $A V l$ gene diagnostic for subgroup III geminiviruses (83). PCR results corroborated results
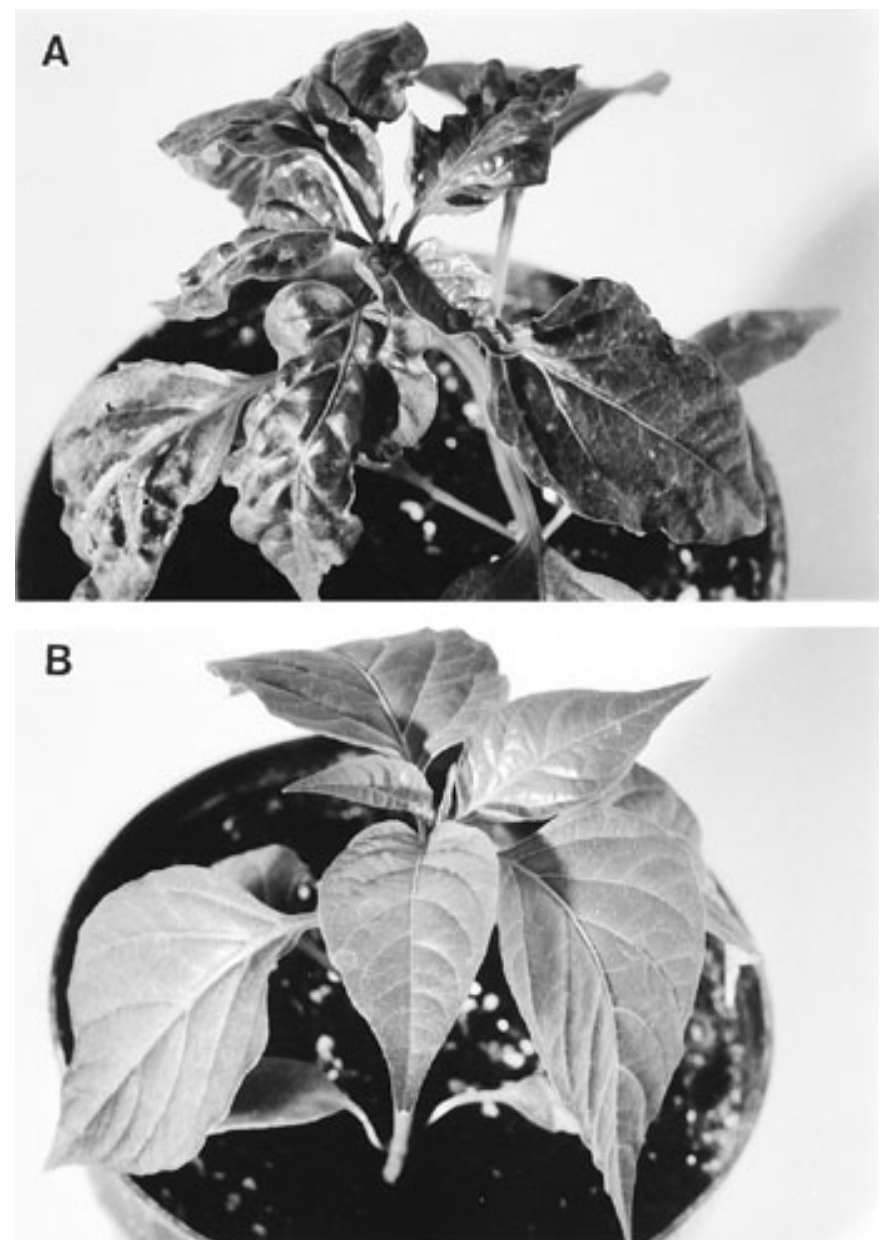

Fig. 3. A, Symptoms in a pepper plant infected with Sinaloa tomato leaf curl geminivirus 2 to 3 weeks postinoculation; B, healthy pepper plant. 
obtained in vector-mediated transmission experiments (data not shown).

Mechanical inoculation. Attempts to mechanically transmit STLCV from tomato to D. metel, D. stramonium, $N$. tabacum cv. Samsun, pepper, or tomato were unsuccessful in three experiments. However, infection was achieved by mechanical inoculation with sap extract from two of six $N$. benthamiana plants that exhibited foliar mottling and stunting 8 to 9 DPI. Positive geminivirus infection was confirmed by PCR (data not shown), a result not corroborated by WFT experiments, because $B$. tabaci does not feed on $N$. benthamiana.

Virus-vector relations. Groups of 15 whiteflies allowed an AAP as brief as $0.5 \mathrm{~h}$ failed to transmit STLCV. Positive transmission was achieved routinely, however, when whiteflies were permitted AAPs of $1,2,4,10,12$, or $18 \mathrm{~h}$. Longer AAPs generally resulted in higher transmission frequencies. Whiteflies given a 24-h AAP on virus-infected plants followed by a 0.5 -h IAP did not transmit STLCV, but transmission was demonstrated when whiteflies were given a 24-h AAP with longer IAPs of 1, 2, 4, 19, 12, or $18 \mathrm{~h}$ (Table 2).

STLCV persisted in single adult whiteflies for up to 9 days, based on development of STLCV symptoms in tomato seedlings inoculated by single whiteflies (Table 3 ). Evaluation of single whiteflies for the ability to serially transmit STLCV for 14 consecutive days indicated that virus transmission was intermittent, in that at least 1 or more of the 10 whiteflies examined (per replicate) failed to transmit virus during 24-h serial transmissions.

Viruliferous whiteflies permitted to mate and oviposit on cotton seedlings (a nonhost of STLCV) were unable to pass STLCV to their first generation progeny, based on the inability of progeny to transmit STLCV to tomato seedlings immediately after eclosion, indicating that STLCV was not transovarially transmitted to adult offspring of the A biotype whitefly vector.

STLCV molecular sequences. PCR primer pairs yielded the following products of expected size amplified from extracts of STLCVinfected tomato leaves: a 1,747-bp product was amplified with prAV1134 with AC344; a 1,156-bp PCR product was amplified with prAV2644 with AC1154; and a 1,410-bp product was amplified with prBV1855 with BC656. Nucleotide sequences obtained from cloned PCR products were used to construct a master sequence for STLCV CR-A and -B fragments; each CR was $174 \mathrm{nt}$ long. Alignment of the STLCV CR-A and -B sequences by Align (DNASTAR) (Fig. 4) indicated a shared identity of $97.7 \%$ between the cloned CR sequences of STLCV.

The CR sequences (174 nt) obtained from the cloned fragments of STLCV A and B genomic components contained identical sequence elements reported to be involved in replication and transcriptional regulation of WFT geminiviruses (31). A specific sequence

TABLE 2. Minimum effective acquisition access periods (AAP) and minimum effective inoculation access periods (IAP) for whitefly transmission of Sinaloa tomato leaf curl virus (STLCV) to tomato plants ${ }^{\mathrm{a}}$

\begin{tabular}{cccc}
\hline AAP & $\begin{array}{c}\text { Symptomatic plants/ } \\
\text { inoculated plants }(\%)^{\mathrm{b}}\end{array}$ & IAP & $\begin{array}{c}\text { Symptomatic plants/ } \\
\text { inoculated plants }(\%)^{\mathrm{b}}\end{array}$ \\
\hline $0.5 \mathrm{~h}$ & $0 / 15(0)$ & $0.5 \mathrm{~h}$ & $0 / 15(0)$ \\
$1 \mathrm{~h}$ & $1 / 11(9)$ & $1 \mathrm{~h}$ & $2 / 15(13)$ \\
$2 \mathrm{~h}$ & $2 / 15(13)$ & $2 \mathrm{~h}$ & $1 / 15(7)$ \\
$4 \mathrm{~h}$ & $4 / 15(27)$ & $4 \mathrm{~h}$ & $8 / 15(53)$ \\
$10 \mathrm{~h}$ & $7 / 10(70)$ & $10 \mathrm{~h}$ & $8 / 10(80)$ \\
$12 \mathrm{~h}$ & $13 / 15(87)$ & $12 \mathrm{~h}$ & $11 / 15(73)$ \\
$18 \mathrm{~h}$ & $15 / 15(100)$ & $18 \mathrm{~h}$ & $11 / 15(73)$ \\
\hline
\end{tabular}

a The minimum AAP was determined by allowing groups of 10 to 25 whiteflies various AAPs on STLCV-infected tomato plants, followed by a 48 -h IAP on tomato test plants. The minimum IAP was determined by allowing groups of whiteflies a 24-h AAP on STLCV-infected tomato plants with various IAPs on tomato plants.

${ }^{b}$ Number of plants with symptoms/total number of inoculated plants. element playing a putative role in replication was identifiable in STLCV sequences. This element contained two 5'-TGGG-3' direct repeats involved in Rep protein binding and the conserved TAATATT*AC sequence and cleavage site $(*)$ (27) at which geminivirus replication is initiated $(6,33,53,55)$.

Specific CR sequence elements have been implicated in transcriptional regulation of certain subgroup III geminivirus genes (33). Using a molecular genetics approach, precise sequence elements have been identified for TGMV, a well-studied geminivirus (31). Analogous elements were identified in the STLCV CR sequences obtained here and were identical between the A- and Bcomponent CRs, as would be expected for cognate components of the same virus. Specifically, STLCV contains two readily identifiable putative $c i s$ sequence elements involved in transcriptional regulation: a G-rich region (or G-box) and a TATA box $(6,55)$ (Fig. 4).

Alignment of the STLCV A-component CR sequence with the CRs of representative members of the three geminivirus subgroups, including all tomato-infecting subgroup III viruses and several viruses from subgroups I and II, indicated a range of 23 to $61 \%$ sequence identity between the STLCV CR and the CRs of other geminiviruses (Table 4), strongly supporting the hypothesis that STLCV is a unique, previously uncharacterized virus. STLCV $\mathrm{CR}-\mathrm{A}$ and -B sequences were assigned GenBank accession numbers AF050632 and AF050633, respectively.

Based on sequence alignment of cloned PCR fragments obtained with primers prAV2644 and prAC1154, the primers amplified the right half of the A component containing the STLCV AV1 ORF, as was predicted. Sequences were examined in three possible reading frames to identify the ORF encoding the STLCV capsid gene. A single putative ORF (756 nt) capable of encoding a polypeptide containing 251 amino acids of $\approx 29 \mathrm{kDa}$ was identified. These features are in line with those of the AV1 ORFs of numerous other WFT geminiviruses. Interestingly, the AV1 ORF of STLCV AV1 is slightly shorter than the analogous ORF of most Eastern Hemisphere WFT geminiviruses, a feature that it shares with other New World WFT geminiviruses. The STLCV AV1 sequence has been assigned GenBank accession number AF040635.

Pairwise comparisons of STLCV AV1 sequences with CP gene sequences of 31 other geminiviruses (Align, DNASTAR) indicated nucleotide sequence identities ranging between 18 and $83.6 \%$, whereas the STLCV predicted amino acid sequence of the capsid protein was 11.1 to $90.1 \%$ identical to other geminiviruses. Comparison of STLCV AV1 nucleotide sequences with other WFT

TABLE 3. Persistence of Sinaloa tomato leaf curl virus (STLCV) in a single adult whitefly (Bemisia tabaci) given a 48-h acquisition access period (AAP) on virus source plants

\begin{tabular}{lcccccccccc}
\hline $\begin{array}{l}\text { Serial } \\
\text { transfer } \\
\text { (days) }\end{array}$ & 1 & 2 & 3 & 4 & 5 & 6 & 7 & 8 & 9 & 10 \\
\cline { 2 - 10 } & \multicolumn{10}{c}{ Whitefly $^{\mathrm{b}}$} \\
\hline 1 & + & - & + & - & + & - & - & - & - & + \\
3 & + & - & + & - & - & + & + & - & - & - \\
4 & + & - & - & - & - & + & - & - & + & + \\
5 & - & - & - & + & - & + & - & + & + & + \\
6 & - & - & + & + & + & - & - & + & + & + \\
7 & + & - & - & - & + & + & - & - & + & + \\
8 & + & - & - & L & L & + & L & L & - & - \\
9 & - & - & + & & & + & & & + & + \\
10 & L & - & - & & & + & & & + & + \\
11 & & - & - & & & - & & & - & - \\
12 & & - & - & & & - & & & - & - \\
13 & & - & - & & & - & & & - & - \\
14 & & - & - & & & - & & & L & - \\
\hline & & L & L & & & L & & & & - \\
\hline
\end{tabular}

a Serial transfer of single whiteflies given a 48-h AAP on STLCV-infected tomato plants.

b + indicates typical STLCV symptoms developed; - indicates no symptoms developed; and L indicates whitefly lost or dead. 
viruses indicated that STLCV shared the greatest identity with members of this virus cluster within the family; however, the STLCV nucleotide sequence was less than $90 \%$ similar to any subgroup III geminivirus described to date (Table 4).

Calculated percent mean identities (MegAlign, DNASTAR) converted from the dissimilarity matrix produced by Clustal pairwise comparisons of STLCV AV1 with AV1 ORFs of all available subgroup III viruses were 56.9 to $83.6 \%$ for STLCV and all subgroup III viruses, 74.6 to $83.6 \%$ for STLCV and all other Western Hemisphere viruses, and 56.9 to $64.9 \%$ for STLCV with all Eastern Hemisphere subgroup III viruses, respectively. MP analysis produced a single most parsimonious tree 3,979 in length in which STLCV was positioned on a branch separated from the other subgroup III viruses but within the polytomy containing all other subgroup III viruses. Further, STLCV was clearly positioned with other geminiviruses originating in the Western Hemisphere cluster (Fig. 5).

\section{DISCUSSION}

The combined unique biotic characteristics along with molecular sequences from key regions of the geminivirus genome, namely those of the $\mathrm{CP}$ gene and $\mathrm{CR}$, permit the provisional description of STLCV as a unique, previously uncharacterized geminivirus. STLCV can be distinguished from other geminiviruses by its moderately narrow host range, which includes only cultivated or weed species within the Solanaceae and Malvaceae. STLCV infection causes a symptomatic infection in pepper, tomato, and tobacco, all solanaceous hosts with known centers of diversity in the New World, whereas it causes a symptomless infection in eggplant, a species originating in the Old World. Further, STLCV is sap transmissible only with difficulty to $N$. benthamiana and causes leaf curling and bright yellow foliar mosaic symptoms and purpling on the abaxial surface of tomato leaves and a green-yellow mottle in pepper. Collectively, these symptoms distinguish STLCV from other geminiviruses of solanaceous hosts in the Western Hemisphere $(18,19,76)$.

Although these data indicate STLCV is a distinct geminivirus, disease caused by STLCV in pepper or tomato could be easily confused with other well-characterized geminiviruses if diagnosis is based solely on symptom and transmission phenotypes. It can be distinguished from TPV-D, in that TPV-D causes distortion and stunting in pepper and a mild mosaic and stunting in tomato. PHV infection results in severe leaf curling and mosaic in both tomato and pepper, and both viruses are more readily sap transmissible than is STLCV $(80,81)$. PMTV differs in that it causes mild leaf curling in tomato and a bright yellow splotchy mottle in pepper and is not mechanically transmissible (13). The newly discovered TTMoV from Cuba (67) is incompletely characterized, but the
$A V 1$ sequence and disease phenotype of TTMoV indicate STLCV and TTMoV are distinct. Tomato yellow mosaic virus from Venezuela (52) and ToMoV from Florida (66) are both readily mechanically transmissible, cause various degrees of yellow mosaic and leaf curling symptoms in tomato, and are not reported to infect pepper. STLCV is readily distinguished from most tomatoinfecting geminiviruses from the Eastern Hemisphere that cause leaf curl symptoms in tomato, in that most of the characterized viruses cause shortened internodes and stunting, are primarily not mechanically transmissible, and are clearly positioned on the AVI tree with other Old World geminiviruses $(3,20,45,50,61,68)$.

To our knowledge, this is the first report of a geminivirus from the Americas that infects eggplant. Although STLCV was discovered in Mexico just prior to the documented establishment of the B biotype vector in the region (25), eggplant has not been formally surveyed as a prospective host, although it is commonly cultivated near tomatoes and peppers in the region. Whereas the A

TABLE 4. Percent similarities in nucleotide and predicted amino acid sequences of the AV1 open reading frame and common region (CR) sequences of Sinaloa tomato leaf curl virus compared to those of representative geminiviruses by MegAlign ${ }^{\mathrm{a}}$

\begin{tabular}{lccc}
\hline Virus & $\begin{array}{c}\text { Nucleotide } \\
\text { AV1 }\end{array}$ & $\begin{array}{c}\text { Amino } \\
\text { Acid AV1 }\end{array}$ & $\begin{array}{c}\text { DNA } \\
\text { CR-A }\end{array}$ \\
\hline Abutilon mosaic virus & 79.6 & 87.7 & 58.5 \\
Tomato leaf crumple virus & 83.6 & 89.7 & 77.6 \\
Tobacco yellow dwarf virus & 20.6 & 11.1 & 23.1 \\
Tomato pseudo-curly top virus & 23.0 & 14.4 & 34.2 \\
Potato yellow mosaic virus & 79.9 & 88.5 & 44.2 \\
Indian tomato leaf curl virus & 62.3 & 70.2 & 33.3 \\
Tomato golden mosaic virus & 81.3 & 87.5 & 56.4 \\
Squash leaf curl virus, E & 80.2 & 90.1 & 36.7 \\
Tomato mottle virus & 79.4 & 86.9 & 57.8 \\
Texas pepper virus & 78.3 & 86.5 & 51.7 \\
Bean golden mosaic virus, Brazil & 76.2 & 86.5 & 58.5 \\
Bean golden mosaic virus, Puerto & & & \\
$\quad$ Rico & 76.0 & 85.6 & 47.6 \\
Pepper hausteco virus & 74.6 & 85.3 & 61.9 \\
Tomato leaf curl virus, Australian & 61.6 & 69.4 & 39.5 \\
Tomato leaf curl virus, New Delhi & 61.2 & 70.2 & 36.7 \\
Tomato yellow leaf curl virus, & & & \\
$\quad$ Thailand & 60.2 & 67.9 & 37.4 \\
Tomato yellow leaf curl virus, Israel & 60.1 & 66.3 & 38.1 \\
Tomato yellow leaf curl virus, & & & \\
$\quad$ Sardinia & 57.0 & 61.9 & 39.5 \\
African cassava mosaic virus, Kenya & 56.9 & 63.5 & 36.1 \\
Maize streak virus & 22.4 & 11.8 & 23.8 \\
Beet curly top virus & 21.8 & 12.3 & 46.2 \\
\hline G
\end{tabular}

${ }^{a}$ Geminivirus DNA reference sequences were obtained from GenBank.
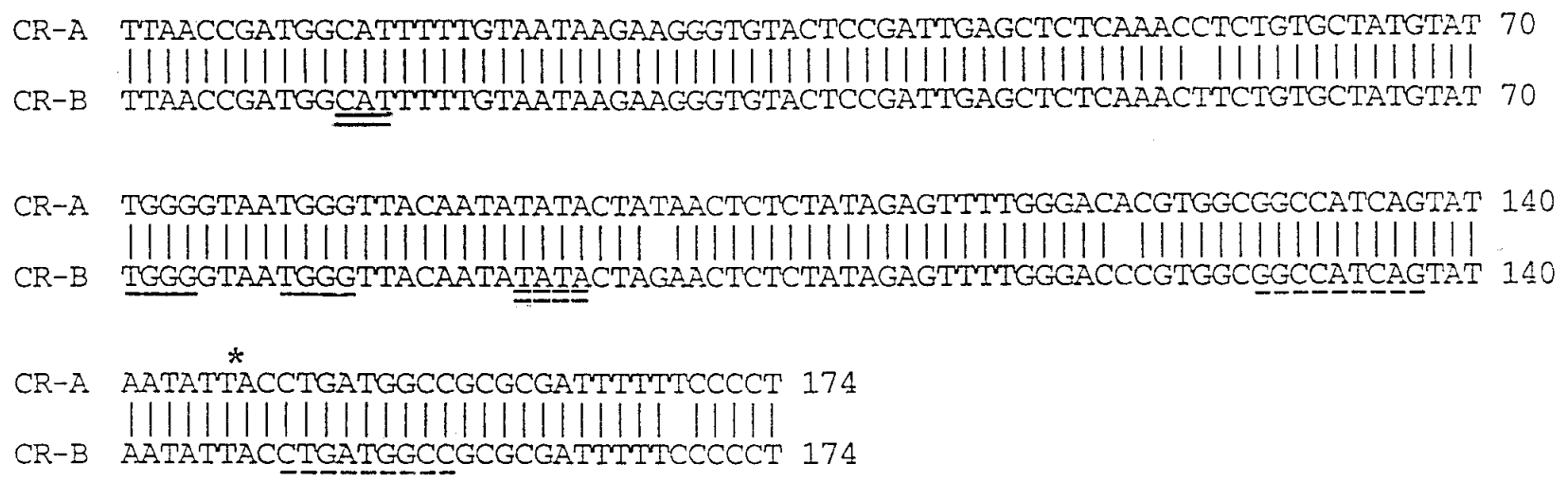

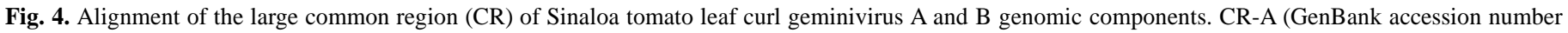

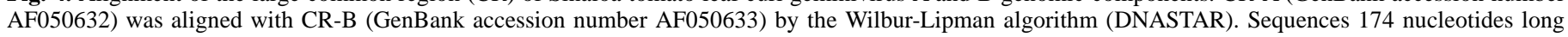

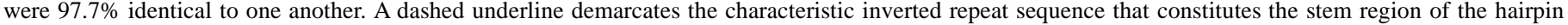

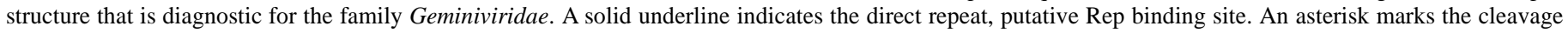

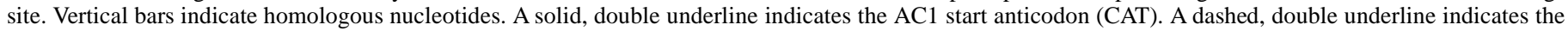
TATA box. 
biotype vector that once predominated only rarely colonizes eggplant (J. Brown, unpublished data), the B biotype vector is now common and readily colonizes eggplant, creating the possibility that eggplant is a natural, asymptomatic reservoir of STLCV. It also is possible that the propensity of the B biotype whitefly to colonize eggplant has provided additional selection pressure favoring widespread natural infection of eggplant and greater dispersion of STLCV during recent years. In the onslaught of the even more recent emergence of "new" tomato-infecting geminiviruses associated with the B biotype vector, it is unknown how widespread or prevalent STLCV is in vegetable production efforts on the West Coast of Mexico or in crop production elsewhere in the Americas. Another geminivirus isolate, designated PVW-C, has incited STLCV-like symptoms in pepper near Weslaco, TX, and shares greater than $95 \%$ sequence $A V 1$ identity with STLCV, indicating STLCV was present in Texas pepper fields as early as 1988 and 1989 (J. K. Brown, unpublished data), just after the B biotype vector invaded the Rio Grande Valley and northern Mexico.
As with other WFT geminiviruses $(7,18,19,21,73)$, STLCV is transmitted in a persistent manner by single viruliferous whiteflies, and increasingly longer exposure to virus-infected plants results in increasingly greater transmission frequency. Further, as with other persistently transmitted viruses, STLCV is transmissible by the whitefly for at least 10 days given a sufficiently lengthy AAP, although intermittent transmission observed for single whiteflies can not be readily explained. A similar result has been reported for several other WFT geminiviruses, including cotton leaf crumple (17) and CdTV (18); however, the reason for these observations is not apparent. Also consistent with other WFT geminiviruses, STLCV is not passed transovarially to offspring by viruliferous parents.

The STLCV A- and B-component CR master sequences have identical conserved regions of $\approx 174$ nt that share $97.7 \%$ sequence identity (Fig. 4), indicating these PCR-derived clones represent cognate A and B viral components of STLCV and STLCV has a bipartite genome organization. The $100 \%$ identity in replication-

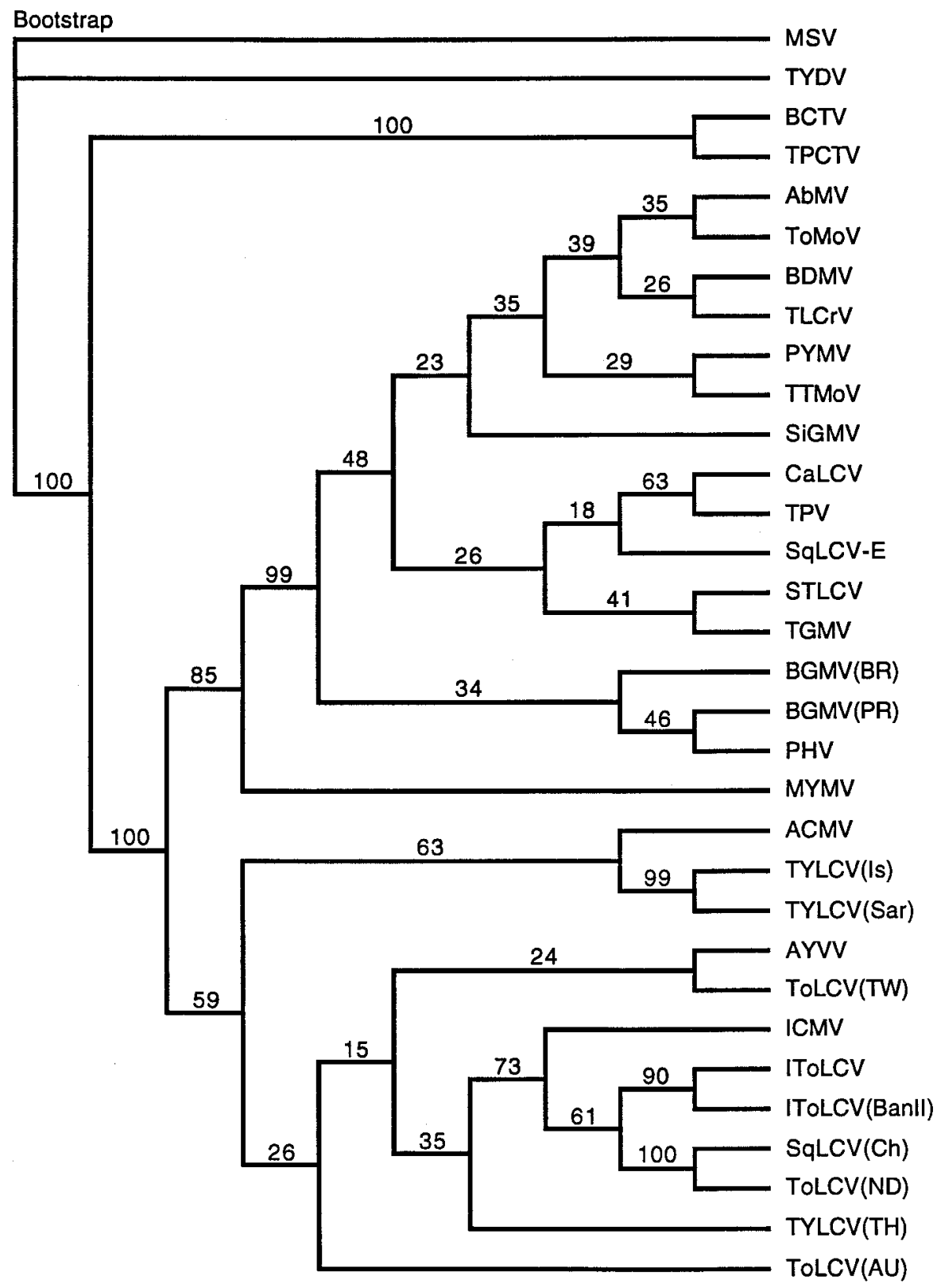

Fig. 5. PAUP (79) reconstruction of a phylogeny of the coat protein gene (AV1), resulting from comparison of Sinaloa tomato leaf curl geminivirus with the nucleotide sequences of 32 other geminivirus taxa. A single most parsimonious tree length of 3,979 was obtained by the heuristic search method with stepwise addition, tree bisection-reconnection branch-swapping options, and 100 bootstrap replicates. Bootstrap values, using the 50\% majority rule option, are indicated on the nodes. 
essential sequences and those involved in transcriptional regulation of the A and B CR STLCV permit the prediction that the viral components would be readily compatible if obtained as full-length infectious clones. Analogous CR sequences have not been reported for any other geminivirus described to date.

Pairwise sequence comparisons (Wilbur-Lipman) between the $A V 1$ of STLCV and 36 other geminiviruses indicate estimated nucleotide and amino acid sequence identities ranging between 18 and $83.6 \%$ and 11.1 and $90.1 \%$, respectively. STLCV $A V 1$ shares 56.9 to $83.6 \%$ identity with nucleotide sequences of 27 other subgroup III viruses, including 4 strains of BGMV and 2 strains of ACMV. These values may be contrasted with the nucleotide similarities of 95.7 to $98.6 \%$ identity between strains of BGMV (DR, $\mathrm{Ga}$, Jam, and PR), or likewise, to $97 \%$ sequence identity between described strains of ACMV from Kenya and Nigeria. Further, the STLCV AV1 ORF sequence shared its lowest nucleotide identities with subgroup II BCTV (21.8\%), a leafhopper-transmitted geminivirus capable of infecting tomato, and subgroup I representative MSV (22.4\%) (Table 4). Clearly, the high degree of predicted amino acid sequence similarity between STLCV AV1 and AV1 sequences for other subgroup III viruses (Table 4) and the low shared identities observed for subgroup I and II viruses support the contention that STLCV is a typical WFT subgroup III geminivirus and highly divergent from subgroups I and II with Cicadellidae vectors.

Based on the AV1 nucleotide sequences of subgroup III and the two outgroup sequences, STLCV is most like TLCrV (84\%), a virus described from the same region of Mexico in 1994 (64), whereas the two next most closely related AV1 sequences are from TGMV (Brazil) and SqLCV-E (Sonoran Desert of Arizona and California, Baja California, and Sonora, Mexico). However, a comparison of STLCV and TLCrV CR sequences leads to the prediction that these two viruses are incompatible with respect to replicationally and transcriptionally important elements. Also, the CR sequence of TLCrV, the virus most closely related to STLCV, has a CR that is nearly identical to the CR of CdTV (80), and the latter two sequences share only $77.6 \%$ sequence identity with STLCV. Further, CdTV and TLCrV CR sequences have a predicted Rep binding motif composed of a $5^{\prime}$-GGGG-3' direct repeat, compared to the STLCV direct repeat, 5'-TGGG-3'. Although CdTV and TLCrV also have origins in the West Coast Mexico, their $A V l$ genes are more like geminiviruses in the AbMV, ToMoV, and BDMV cluster; consequently, STLCV does not appear to be a strain of any of its closest relatives, based on either CR or AVI sequences.

The current studies provide ample evidence for the partial characterization of a new geminivirus of tomato from the Western Hemisphere, based on combined comparative biotic and molecular sequence data, in the absence of full-length infectious clones and a complete genomic sequence. Given the magnitude of the effort required to characterize the plethora of emergent geminiviruses on a global scale, the approach described here promises substantial reprieve from the time-consuming need to sequence full-length infectious clones to accomplish tentative virus identification and taxonomic placement. Specifically, these results show that an abbreviated approach that relies on experimental host range data and associated symptom and transmission phenotypes and key sequences of AV1 ORF and A- and B-component CR, accessible by PCR with the primers described here, provide a reliable means of achieving tentative virus identification and knowledge about whether the virus has a bipartite or monopartite genome.

This strategy does not serve as a replacement for obtaining complete sequence information and full-length infectious virus clones but does provide a useful, rapid means of determining whether a potentially new virus has been discovered and should be given priority in obtaining infectious clones and their DNA sequences. Further, it is clear that partial sequence data do not necessarily reveal whether an emergent geminivirus represents the progeny of one or more recombination or pseudorecombination events in the absence of detailed in vivo studies that require a full complement of biological and molecular information.

In this study, we addressed the utility of an abbreviated molecular analysis, combined with biologically based experiments, for efficient initial characterization of WFT geminiviruses. Using this approach, the distinct biological and molecular properties reported for STLCV support our hypothesis that STLCV is a new, previously uncharacterized tomato-infecting subgroup III geminivirus with an extant origin in the New World.

\section{ACKNOWLEDGMENTS}

A Ph.D. fellowship was generously provided to A. M. Idris by the Margoes Foundation, San Francisco, CA. Additional funding for operations and travel was generously provided by the U.S. Department of Agriculture, Foreign Agriculture Service/Office of International Cooperation. We thank S. D. Wyatt, Washington State University, Pullman, for collaborative interactions and for assistance in PCR primer design.

\section{LITERATURE CITED}

1. Abouzid, A. M., Hiebert, E., and Strandberg, J. O. 1992. Cloning, identification, and partial sequencing of the genomic components of a geminivirus infecting the Brassicaceae. (Abstr.) Phytopathology 82:1070.

2. Abouzid, A. M., Polston, J. E., and Hiebert, E. 1992. The nucleotide sequence of tomato mottle virus, a new geminivirus isolated from tomatoes in Florida. J. Gen. Virol. 73:3225-3229.

3. Antignus, Y., and Cohen, S. 1994. Complete sequence of an infectious clone of a mild isolate of tomato yellow leaf curl virus (TYLCV). Phytopathology 84:707-712.

4. Bedford, I. D., Markham, P. G., Brown, J. K., and Rosell, R. C. 1994. Geminivirus transmission and biological characterization of whitefly (Bemisia tabaci) biotypes from different geographic regions. Ann. Appl. Biol. 125:311-325.

5. Bird, J., and Maramorosch, K. 1978. Viruses and virus diseases associated with whiteflies. Adv. Virus Res. 22:55-110.

6. Bisaro, D. M. 1996. Geminivirus DNA replication. Pages 833-854 in: DNA Replication in Eukaryotic Cells. M. DePamphilis, ed. Cold Spring Harbor Laboratory Press, Cold Spring Harbor, NY.

7. Bock, K. R., and Guthrie, E. J. 1978. Transmission of African cassava mosaic by mechanical inoculation. Plant Dis. Rep. 62:580-581.

8. Briddon, R. W., Bedford, I. D., Tsai, J. H., and Markham, P. G. 1996. Analysis of the nucleotide sequence of the treehopper-transmitted geminivirus, tomato pseudo-curly top virus, suggests a recombinant origin. Virology 219:387-394.

9. Brown, J. K. 1990. An update on the whitefly-transmitted geminiviruses in the Americas and the Caribbean basin. FAO Plant Prot. Bull. 39:5-23.

10. Brown, J. K. 1994. Current status of Bemisia tabaci as a pest and virus vector in world agroecosystems. FAO Plant Prot. Bull. 42:3-32.

11. Brown, J. K. 1996. The Biology and molecular epidemiology of the Geminiviridae subgroup III. Pages 125-195 in: Plant-Microbe Interactions Review Series. G. Stacey and N. Keen, eds. Chapman and Hall, New York.

12. Brown, J. K., and Bird, J. 1992. Whitefly-transmitted diseases in the Americas and the Caribbean Basin: Past and present. Plant Dis. 76:220225.

13. Brown, J. K., Campodonico, O. P., and Nelson, M. R. 1989. A whiteflytransmitted geminivirus from peppers with tigre disease. Plant Dis. 73:610.

14. Brown, J. K., Coats, S., Bedford, I. D., Markham, P. G., Bird, J., and Frohlich, D. R. 1995. Characterization and distribution of esterase electromorphs in the whitefly, Bemisia tabaci (Genn.) (Homoptera: Aleyrodidae). Biochem. Genet. 33:205-214.

15. Brown, J. K., Frohlich, D. R., and Rosell, R. C. 1995. The sweetpotato/ silverleaf whiteflies: Biotypes of Bemisia tabaci Genn., or a species complex? Annu. Rev. Entomol. 40:511-534.

16. Brown, J. K., Idris, A. M., and Fletcher, D. C. 1993. Sinaloa tomato leaf curl virus, a newly described geminivirus of tomato and pepper in West Coastal Mexico. Plant Dis. 77:1262.

17. Brown, J. K., and Nelson, M. R. 1986. Host range study of the cotton leaf crumple virus. Ariz. Agric. Exp. Stn. P-63:171-176.

18. Brown, J. K., and Nelson, M. R. 1988. Transmission, host range, and virus-vector relationships of chino del tomate virus, a whitefly-transmitted geminivirus from Sinaloa, Mexico. Plant Dis. 72:866-869.

19. Brown, J. K., and Poulos, B. T. 1990. Serrano golden mosaic virus: A newly identified whitefly-transmitted geminivirus of pepper and tomato in the United States and Mexico. Plant Dis. 74:720.

20. Chatchawankanphanich, O., Chiang, B. T., Green, S. K., Sing, S. J., Mehta, 
P., and Maxwell, D. P. 1993. Nucleotide sequence of a geminivirus associated with tomato leaf curl virus from India. Plant Dis. 77:1168.

21. Cohen, S., Duffus, J. E., Larsen, R. C., Liu, H. Y., and Flock, R. A. 1983. Purification, serology, and vector relationships of squash leaf curl virus, a whitefly-transmitted geminivirus. Phytopathology 73:1669-1673.

22. Costa, A. S. 1976. Whitefly-transmitted plant diseases. Annu. Rev. Phytopathol. 14:429-449.

23. Costa, A. S., and Russell, L. M. 1975. Failure of Bemisia tabaci to breed on cassava plants in Brazil (Homoptera: Aleyrodidae). Cienc. Cult. (Sao Paulo) 27:388-390.

24. Costa, H. S., and Brown, J. K. 1991. Variation in biological characteristics and in esterase patterns among populations of Bemisia tabaci Genn. and the association of one population with silverleaf symptom development. Entomol. Exp. Appl. 61:211-219.

25. Costa, H. S., Brown, J. K., Sivasupramaniam, S., and Bird, J. 1993. Regional distribution, insecticide resistance, and reciprocal crosses between the A and B biotypes of Bemisia tabaci. Insect Sci. Appl. 14:127-138.

26. Coutts, R. H. A., Coffin, R. S., Roberts, E. J. F., and Hamilton, W. D. O. 1991. The nucleotide sequence of the infectious cloned DNA components of potato yellow mosaic virus. J. Gen. Virol. 72:1515-1520.

27. Desbiez, C., David, C., Mettouchi, A., Laufs, J., and Gronenborn, B. 1995. Rep protein of tomato yellow leaf curl geminivirus (TYLCV) has an ATPase activity required for viral DNA replication. Proc. Natl. Acad. Sci. USA 92:5640-5644.

28. Donson, J., Accotto, G. P., Boulton, M. I., Mullineaux, P. M., and Davies, J. W. 1987. The nucleotide sequence of a geminivirus from Digitaria sanguinalis. Virology 161:160-169.

29. Doyle, J. J., and Doyle, J. L. 1987. A rapid DNA isolation procedure for small quantities of fresh leaf tissue. Phytochem. Bull. 19:11-15.

30. Dry, I. B., Rigden, J. E., Krake, L. R., Mullineaux, P. M., and Rezaian, A. M. 1993. Nucleotide sequence and genome organization of tomato leaf curl geminivirus. J. Gen. Virol. 74:147-151.

31. Eagle, P. A., and Hanley-Bowdoin, L. 1997. cis Element that contributes to geminivirus transcriptional regulation and the efficiency of DNA replication. J. Virol. 71:6947-6955.

32. Faria, J. C., Gilbertson, R. L., Hanson, S. F., Morales, F. J., Ahlquist, P. G., Loniello, A. L., and Maxwell, D. P. 1994. Bean golden mosaic geminivirus type II isolates from the Dominican Republic and Guatemala: Nucleotide sequences, infectious pseudorecombinants, and phylogenetic relationships. Mol. Plant Pathol. 84:321-329.

33. Fontes, E. P. B., Eagle, P. A., Sipe, P. S., Luckow, V. A., and HanleyBowdoin, L. 1994. Interaction between a geminivirus replication protein and origin DNA is essential for viral replication. J. Biol. Chem. 269:84598465 .

34. Frischmuth, T., Zimmat, G., and Jeske, H. 1990. The nucleotide sequence of Abutilon mosaic virus reveals prokaryotic as well as eukaryotic features. Virology 178:461-468.

35. Frohlich, D. R., Brown, J. K., Bedford, I. A., and Markham, P. G. 1996. Mitochondrial 16S ribosomal subunit as a molecular marker in Bemisia, and implications for population variability. Page 702 in: Bemisia 1995: Taxonomy, Biology, Damage, Control and Management. D. Gerling and R. T. Mayer, eds. Intercept Ltd., Andover, England.

36. Gallegos, H. M. L. 1978. Enchinamiento del tomate (chino disease of tomato). Pages 1-119 in: Enfermedades de Cultivos en el Estado de Sinaloa. Secretia de Agricultura y Recursos Hidraulicos, Sinaloa, Mexico.

37. Garzón-Tiznado, J. A., Torres-Pacheco, I., Ascencio-Ibañez, J. T., HerreraEstrella, L., and Rivera-Bustamante, R. F. 1993. Inoculation of peppers with infectious clones of a new geminivirus by a biolistic procedure. Phytopathology 83:514-521.

38. Gilbertson, R. L., Hidayat, S. H., Paplomatas, E. J., Rojas, M. R., Hou, Y., and Maxwell, D. P. 1993. Pseudorecombination between infectious cloned DNA components of tomato mottle and bean dwarf mosaic geminivirus. J. Gen. Virol. 74:23-31.

39. Hamilton, W. D. O., Stein, V. E., Coutts, R. H. A., and Buck, K. W. 1984. Complete nucleotide sequence of the infectious cloned DNA components of tomato golden mosaic virus: Potential coding regions and regulatory sequences. EMBO J. 3:2197-2205.

40. Harrison, B. D., and Robinson, D. J. 1988. Molecular variation in vectorborne plant viruses: Epidemiological significance. Phil. Trans. R. Soc. Lond. B 321:447-462.

41. Heyraud-Nitschke, F., Schumacher, S., Lauf, J., Schaefer, S., Schell, J., and Bronenborn, B. 1995. Direction of the origin cleavage and joining domain of geminivirus Rep proteins. Nucl. Acids Res. 23:910-916.

42. Hidayat, S. H., Gilbertson, R. L., Hanson, S. F., Morales, F. J., Ahlquist, P. G., Russel, D. R., and Maxwell, D. P. 1993. Complete nucleotide sequences of the infectious cloned DNAs of bean dwarf mosaic geminivirus. Phytopathology 83:181-187.

43. Hofer, P., Engel, M., Jeske, H., and Frischmuth, T. 1997. Nucleotide sequence of a new bipartite geminivirus isolated from the common weed
Sida rhombifolia in Costa Rica. J. Gen. Virol. 78:1785-1790.

44. Hong, Y., Wang, X., Tian, B., and Cai, J. 1995. Chinese squash leaf curl virus: A new whitefly-transmitted geminivirus. Sci. China Ser. B Chem. Life Sci. \& Earth Sci. 38:179-186.

45. Hong, Y. G., and Harrison, B. D. 1995. Nucleotide sequence from tomato leaf curl virus from different countries: Evidence for three geographically separate branches in evolution of coat protein of whitefly-transmitted geminiviruses. J. Gen. Virol. 76:2043-2049.

46. Hong, Y. G., Robinson, D. J., and Harrison, B. D. 1993. Nucleotide sequence evidence for the occurrence of three distinct whitefly-transmitted geminiviruses in cassava. J. Gen. Virol. 74:2437-2443.

47. Howarth, A. J., Caton, J., Bossert, M., and Goodman, R. M. 1985. Nucleotide sequence of bean golden mosaic virus and a model for gene regulation in geminiviruses. Proc. Natl. Acad. Sci. USA 82:3572-3576.

48. Howell, S. H. 1984. Physical structure and genetic organisation of the genome of maize streak virus (Kenyan isolate). Nucl. Acids Res. 12:73597375.

49. Idris, A. M., Fletcher, D. C., and Brown, J. K. 1993. Identification and partial characterization of Sinaloa tomato leaf curl virus (STLCV), a new whitefly-transmitted geminivirus affecting tomato and pepper from Sinaloa, Mexico. (Abstr.) Phytopathology 83:692.

50. Ioannou, N. 1985. Yellow leaf curl and other virus diseases of tomato in Cyprus. Plant Pathol. 34:428-434.

51. Kheyr-Pour, A., Bendahmane, M., Matzeit, V., Accotto, G. P., Crespi, S., and Gronenborn, B. 1991. Tomato yellow leaf curl virus from Sardinia is a whitefly-transmitted monopartite geminivirus. Nucl. Acids Res. 19:67636769.

52. Lastra, R., and Gil, F. 1981. Ultrastructural host cell changes associated with tomato yellow mosaic. Phytopathology 71:524-528.

53. Laufs, J., Traut, W., Heyraud, F., Matzeit, V., Rogers, S. G., Schell, J., and Gronenborn, B. 1995. In vitro cleavage and joining at the viral origin of replication by the replication protein Rep of tomato yellow leaf curl virus. Proc. Natl. Acad. Sci. USA 92:3879-3883.

54. Lazarowitz, S. G. 1991. Molecular characterization of two bipartite geminiviruses causing squash leaf curl disease: Role of viral replication and movement functions in determining host range. Virology 180:70-80.

55. Lazarowitz, S. G. 1992. Geminiviruses: Genome structure and function. Crit. Rev. Plant Sci. 11:327-349.

56. Morinaga, T., Ikegami, M., and Miura, K. 1993. The nucleotide sequence and genome structure of mung bean yellow mosaic geminivirus. Micro. Immunol. 37:471-476.

57. Morris, B., Coates, L., Lowe, S., Richardson, K., and Eddy, P. 1990. Nucleotide sequence of the infectious cloned DNA components of African cassava mosaic virus (Nigerian strain). Nucl. Acids Res. 18:197-198.

58. Morris, B. A. M., Richardson, K. A., Haley, A., Zhan, X., and Thomas, J. E. 1992. The nucleotide sequence of the infectious cloned DNA component of tobacco yellow dwarf virus reveals features of geminiviruses infecting monocotyledonous plants. Virology 187:633-642.

59. Murphy, F. A., Fauquet, C. M., Bishop, D. H. L., Ghabrial, S. A., Jarvis, A. W., Martelli, G. P., Mayo, M. A., and Summers, M. D. 1995. Classification and nomenclature of viruses: 6th Rep. Int. Commit. Taxonomy Viruses. Arch. Virol. Suppl. 10. Springer-Verlag, New York.

60. Navot, N., Pichersky, E., Zeidan, M., Zamir, D., and Czosnek, H. 1991. Tomato yellow leaf curl virus, a whitefly-transmitted geminivirus with a single genomic component. Virology 185:151-161.

61. Padidam, M., Beachy, R. N., and Fauquet, C. M. 1995. Tomato leaf curl geminivirus from India has a bipartite genome and coat protein is not essential for infectivity. J. Gen. Virol. 76:25-35.

62. Padidam, M., Beachy, R. N., and Fauquet, C. F. 1995. Classification and identification of geminiviruses using sequence comparisons. J. Gen. Virol. 76:249-263.

63. Padidam, M., Beachy, R. N., and Fauquet, C. F. 1996. The role of AV2 (precoat) and coat protein in viral replication and movement in tomato leaf curl geminivirus. Virology 224:390-406.

64. Paplomatas, E. J., Patel, V. P., Hou, Y. M., Noueiry, A. O., and Gilbertson, R. L. 1994. Molecular characterization of a new sap-transmission bipartite genome geminivirus infecting tomatoes in Mexico. Phytopathology 84:1215-1224.

65. Polston, J. A., and Anderson, P. A. 1997. The emergence of whiteflytransmitted geminiviruses in tomato in the Western Hemisphere. Plant Dis. 81:1358-1369.

66. Polston, J. E., Hiebert, E., McGovern, R. J., Stansly, P. A., and Schuster, D. J. 1993. Host range of tomato mottle geminivirus, a new geminivirus infecting tomato in Florida. Plant Dis. 77:1181-1184.

67. Ramos, P. L., Guerra, O., Peral, P., Oramas, P., Guevara, R. G., and RiveraBustamante, R. 1997. Taino tomato mottle virus, a new bipartite geminivirus from Cuba. Plant Dis. 81:1095.

68. Reddy, K. S., and Yaraguntaiah, R. C. 1981. Virus-vector relationship in leaf curl disease of tomato. Indian Phytopathol. 34:310-313. 
69. Rigden, E. J., Krake, L. R., Rezaian, M. L., and Dry, I. B. 1994. ORF C4 of tomato leaf curl geminivirus is a determinant of symptom severity. Virology 204:847-850.

70. Rochester, D. E., DePaulo, J. J., Frauquet, C. M., and Beachy, R. N. 1994. Complete nucleotide sequence of geminivirus tomato yellow leaf curl virus, Thailand isolate. J. Gen. Virol. 75:477-485.

71. Rybicki, E. P. 1994. A phylogenetic and evolutionary justification for three genera of geminiviridae. Arch. Virol. 139:49-77.

72. Saiki, R. K., Gelfand, D. H., Stoffel, S., Scharf, S. J., Higuchi, R., Horn, G. T., Mullis, K. B., and Ehrlich, H. A. 1988. Primer directed enzymatic amplification of DNA with a thermostable DNA polymerase. Science 301:260-262.

73. Srivastava, K. M., Singh, B. P., Dwadash Shreni, V. C., and Srivastava, B. N. 1977. Zinnia yellow net disease-transmission, host range, and agentvector relationship. Plant Dis. Rep. 61:550-554.

74. Stanley, J., and Gay, M. R. 1983. Nucleotide sequence of cassava latent virus DNA. Nature (Lond.) 301:260-262.

75. Stanley, J., Markham, P. G., Callis, R. J., and Pinner, M. S. 1986. The nucleotide sequence of an infectious clone of the geminivirus beet curly top virus. EMBO J. 5:1761-1767.

76. Stenger, D. C., Duffus, J. E., and Villalon, B. 1990. Biological and genomic properties of a geminivirus isolated from pepper. Phytopathology 80:704-709.
77. Sunter, G., and Bisaro, D. M. 1992. Transactivation of geminivirus AR1 and geminivirus BR1 gene expression by the viral AL2 gene product occurs at the level of transcription. Cell 4:1321-1331.

78. Sunter, G., Hartitz, M. D., Hormuzdi, S. G., Brough, C. L., and Bisaro, D. M. 1990. Genetic analysis of tomato golden mosaic virus: ORF AL2 is required for coat protein accumulation while ORF AL3 is necessary for efficient DNA replication. Virology 179:69-77.

79. Swofford, D. L. 1993. PAUP: Phylogenetic Analysis Using Parsimony. Illinois Natural History Survey, University of Illinois, Champaign.

80. Torres-Pacheco, I., Garzón-Tiznado, J. A., Brown, J. K., Becerra-Flora, A., and Rivera-Bustamante, R. F. 1996. Detection and distribution of geminiviruses in Mexico and the southern United States. Phytopathology 86: 1186-1192.

81. Torres-Pacheco, I., Garzón-Tiznado, J. A., Herra-Estrella, L., and BustamanteRivera, R. F. 1993. Complete nucleotide sequence of pepper huasteco virus, analysis and comparison with bipartite geminiviruses. J. Gen. Virol. 74:2225-2231.

82. Wong, S. M., Swanson, M. M., and Harrison, B. D. 1993. A geminivirus causing vein yellowing of Ageratum conyzoides in Singapore. Plant Pathol. 42:137-139.

83. Wyatt, S. D., and Brown, J. K. 1996. Detection of subgroup III geminivirus isolates in leaf extracts by degenerate primers and polymerase chain reaction. Phytopathology 86:1288-1293. 